\title{
Taking Academic Freedom Seriously: Exploring the Legal and Moral Underpinnings of BDS $^{1}$
}

\author{
Jeff Handmaker ${ }^{2}$
}

\begin{abstract}
The call for a cultural and academic boycott of Israel that was launched by Palestinian civil society in 2004 represents a decisive turning point in the long-time Palestinian struggle for social justice and academic freedom and the broader struggle for Palestinian selfdetermination. Alongside petitions, worldwide demonstrations and other national and global advocacy initiatives, as well as a vigorous debate in the alternative and occasionally also the mainstream media, substantial scholarly literature has emerged. This literature introduces legal and moral arguments that underpin the broader call by Palestinian civil society in 2005 for "boycotts, divestment and sanctions (hereinafter "BDS") against Israel until it complies with international law and universal principles of human rights, ${ }^{3}$

This essay builds on some of my earlier reflections and reviews six books (some in more detail than others) from among a growing pool of literature addressing the Palestinian calls for BDS, and the legal and moral justifications that reinforce these calls. I will explore the way in which the authors explain a way out of the impasse between Israel and the Palestinians and develop two positions that emerge from their contributions. Firstly, robust legal arguments, especially if accompanied by moral clarity, can provide a rigorous normative basis for why BDS against Israel is justified. Second, irrespective of one's view regarding BDS, legal explanations alone can be rendered meaningless and can lead to highly misleading conclusions if they are not grounded in a social and political context. This essay will conclude that any discussion on international law and the morality of BDS must critically engage with not only the politics of law and legal institutions, but also the politics of resistance.
\end{abstract}

\section{From scholars to the church: articulating the legal and moral basis of BDS}

The global movement for BDS was quickly established. ${ }^{4}$ The movement, which is composed of a broad cross-section of Palestinian civil society, from academics to Lutheran ministers, has drawn substantially on international law and what many regard as universal moral values. Together, these legal and moral positions provide a robust normative basis in favor of BDS.

BDS has been used before. In 1965, 500 scholars from the United Kingdom protested the South African government's banning of two academics and called for a boycott of South African institutions. Decades later, following Palestinian calls in 2004 and 2005, scholars, lawyers and activists from around the world began responding to the Palestinian call in a coordinated way. Faced with Israel's brutal and unrelenting treatment of the Palestinians and a

\footnotetext{
${ }^{1}$ Review essay of: S. Akram, Michael Dumper, Michael Lynk and Iain Scobbie (2011) International Law and the Israeli-Palestinian Conflict. New York: Routledge 342 pp, Paperback, ISBN: 9780415573238; O. Barghouti (2011) Boycott, Divestment, Sanctions: The Global Struggle for Palestinian Rights. Chicago: Haymarket, 220 pp, Paperback, ISBN: 9781608461141; BRICUP (2007) Why Boycott Israeli Universities? London: British Committee for Universities in Palestine, 35 pp, Paperback, ISBN: 9780955553608; S.D. Dikker Hupkes (2008) What constitutes occupation? Israel as the occupying power in the Gaza Strip after disengagement, Leiden: Jongbloed, $110 \mathrm{pp}$, Paperback, ISBN: 9789070062453; R. Kassis (2011) Kairos for Palestine, Beit Sahour: Badayl/Alternatives, 197 pp, Paperback, ISBN: 9789950346017; I. Pappe (2010) Out of the frame: The struggle for academic freedom in Israel, New York: Pluto Press, 246 pp, Paperback, ISBN: 9780745327259.

${ }^{2}$ Senior lecturer in Law, Human Rights and Development, Erasmus University, International Institute of Social Studies, The Hague, The Netherlands.

${ }^{3}$ For more information, see: www.bdsmovement.net, last checked on 18 January 2012.

${ }^{4}$ This section draws upon and develops J. Handmaker (2007).
} 
corresponding unwillingness or inability by the United Nations (UN), European Union (EU) and powerful countries to take strong action against Israel, scholars around the world have been compelled to yet again revisit the issue of BDS as a matter of intellectual responsibility. ${ }^{5}$ As BRICUP (2007) explains, and as confirmed by Barghouti (2011), scholars have drawn on similar strategies that were employed in relation to South Africa in the 1960s.

The publication by BRICUP outlines in clear and unambiguous language the legal and moral arguments why taking a stand against Israeli academic institutions is justified. Informed by the Palestinian calls for BDS, the document explains how academic freedom is under attack by policies and actions of the State of Israel by, or with the complicity of, the policies and actions of Israeli academic institutions. This is illustrated by numerous examples of institutional victimization, further elaborated by Pappe as part of the broader security regime imposed by Israel that systematically violates human rights and humanitarian law, ${ }^{6}$ reinforcing the underlying message of boycott as 'a combination of symbolic protest, material intervention and political action'?

Carefully measured comparisons are made in the BRICUP publication to the system of radicalized apartheid in South Africa. This is crucial. As Barghouti argues, there is arguably no other event in recent history that has so mobilized British academics to take such a position. Emphasizing what he describes as the 'South African strategy for Palestine', Barghouti develops the apartheid analogy beyond Israel's policy in relation to the occupied Palestinian territories. In relation to Palestinian refugees, he develops the analogy by providing several examples of institutionalized racism and apartheid against Palestinian citizens of Israel as well. ${ }^{8}$ The apartheid analogy is further developed by Pappe's personal account of academic freedom in Israel, the extensive overview by Akram and her colleagues of the treatment of refugees and Palestinians living in Jerusalem and other issues as well as the moving testimonial of Kassis (2011) and his family's brutal treatment by Israel's regime.

If anything could be said to be missing in the BRICUP document, it is additional detail that would further reinforce the authors' central arguments as to why an academic boycott is justified. Omar Barghouti's well-researched book goes much further, explaining the "three forms of injustice that infringe international law and human rights" against Palestinians: (1) in the Israeli-occupied territories of the West Bank and Gaza Strip (hereinafter 'occupied territories'); (2) with Israeli citizenship and (3) who are refugees as the result of various conflicts and oppressive Israeli policies. ${ }^{9}$ Firstly, Barghouti explains how the colonization and discrimination by Israel's military regime against Palestinians in the occupied territories has been accompanied by a legal and administrative regime that does not apply to the several hundred thousand Israeli settlers residing in the occupied territories. Along with the wall and its associated regime, the International Court of Justice confirmed the settlements as illegal in 2004. Although the Supreme Court of Israel has acknowledged some elements of this illegality, the government of Israel has mostly disregarded these judicial decisions. ${ }^{10}$

Secondly, Barghouti and Pappe both explain that discrimination exists in Israel itself for Palestinians who have Israeli citizenship, but are denied Israeli nationality. Finally, Akram et al, Barghouti, Pappe and Kassis comprehensively explain that while the Israeli 'law of return' allows Jews from all over the world to settle in Israel, hundreds of thousands of ethnicallycleansed Palestinians who lived in the territory for centuries, and their descendants, have been denied their right to reclaim and return to their property and lands. Pappe further emphasizes

\footnotetext{
${ }^{5}$ An example of this is a letter by scholars at the ISS in 2014: http://blog.eur.nl/iss/hr/2014/08/05/iss-scholars-staffprotest-gaza-bombings/

${ }^{10}$ S. Akram and M. Lynk (2006). See also: Editorial, 'Making the law a laughingstock', Haaretz, 31/12/2006
} 
how Israel has been incapable of coming to terms with numerous crimes committed by Zionist forces during the war in $1948 .^{11}$

References to further reading in BRICUP's concise publication do, however, make clear that the absence of additional perspectives was merely intended to give the publication focus on the core issue - namely denial of the academic freedom of Palestinians. Unlike the simplistic responses of the boycott detractors, the publication shows that much reflection has taken place. The document comprehensively deals with various 'claims' that have been made against calling for a boycott and seeks, as the authors argue, to 'disentangle fact from myth and innuendo'. ${ }^{12}$ The BRICUP authors make clear that the focus of the boycott is not individual academics as such, but the institutions they work for and 'to provide a compelling moral or practical argument against the continuation of deplorable practices'. ${ }^{13}$ Barghouti develops the arguments in favor of academic and cultural boycott further, providing lucid and comprehensive responses to the main arguments raised against the boycott. ${ }^{14}$

As Barghouti and BRICUP confirm, in the United States, and to some extent in Britain as well, detractors of BDS have argued that it is, in essence, 'anti-semitic'. In other European countries, such as The Netherlands, where the issue of academic boycott has been hardly addressed, scholars and NGOs have raised dubious claims that debate on the issue is impossible so long as most Dutch people possess feelings of collective guilt at the deportation of $80 \%$ of Holland's Jewish population. Regardless of whether this claim is valid or not, it is routinely raised against criticism of Israel in what Barghouti rejects as a form of emotional blackmail. Drawing on other scholars, such as Gavriel Solomon and Sefi Rachlevsky, Barghouti reveals that Israeli Jews are often the first to recognize the marked similarities with Germany in the 1940s. ${ }^{15}$ Nevertheless, the feelings of collective guilt endure in The Netherlands and the resulting self-censorship on the part of Dutch scholars is often accompanied by a persistent refusal to engage in a critical dialogue, where criticisms of Israel, and especially talk of boycotting Israeli institutions are felt to betray the memory of these events. In other words, rather than confronting the guilt, or Islamaphobia that often accompanies this, Dutch academics simply turn a blind eye to Israel's atrocities committed against Palestinians. A similarly deceptive situation exists in other European countries, as highlighted by AURDIP and others. ${ }^{16}$

In order to ground the justification for BDS through Christian morality, Rifat Kassis has produced a compelling book that draws on personal experiences and extensive travels to countries around the world where the notion of "Kairos" (a moment of truth) resonates strongly. Kassis explores both his personal journey and the political journey Palestinians have made in asserting themselves against Israel's regime through civic and non-violent resistance during the uprisings (intifadas) of 1987 and 2000 and especially by way of the Palestinian call for BDS. His contribution to the discussion on the moral underpinnings behind BDS is especially significant in light of the overwhelming financial support and blind loyalty to Israel provided by Christians around the world, and particularly by politically influential, fundamentalist groups in the USA, The Netherlands and elsewhere. ${ }^{17}$

Pappe also reinforces the arguments in favor of BDS and, in particular, cultural and academic BDS, with his personal account as an Israeli-Jewish scholar formerly based at the University of Haifa, and why he felt compelled to leave Israeli academia. After underlining Israel's

\footnotetext{
${ }^{11}$ N. Masalha (2003) and I. Pappe (2007). See also www.badil.org, last checked on 18 January 2012.

12 (pp. 24-31).

13 (p. 20).

${ }^{14}$ (pp. 77-83 and 143-150).

${ }^{15}$ (p. 13).

${ }^{16}$ AURDIP stands for the Association of Academics for the Respect of International Law in Palestine. See: www.aurdip.fr and http://www.pacbi.org/etemplate.php?id=1382

${ }^{17}$ See Christians for Israel International, www.c4israel.org; Christians United for Israel, www.cufi.org and others.
} 
longstanding policies of ethnic cleansing and deliberate cover-up of war crimes, Pappe remarks in the concluding chapter of his book that:

BDS, Boycott, Divestment and Sanctions as a three-tiered strategy for the future has become a valid option because of a fundamental shift in the West. ... The post-Holocaust trauma and guilt complex, military and economic interests and the charade of Israel as the only democracy in the Middle East all played a role in providing immunity for the state of Israel. ... The magnitude of the ethnic cleansing in 1948 is well known, the suffering of the people in the Occupied Territories recorded and described even by the US president as unbearable and inhuman. In a similar way, the destruction and depopulation of the greater Jerusalem area is noted daily and the racist nature of the policies towards the Palestinians in Israel are frequently rebuked and condemned. ${ }^{18}$

The common message contained in the publications by BRICUP, Barghouti, Akram, Pappe and Kassis is that Palestinians are denied their fundamental human rights provided for in international law, including systematic denial of academic freedom, through policies of the State of Israel and - significantly - through the active and passive complicity of Israeli academic institutions with violations of human rights and humanitarian law by the State of Israel. These publications provide irrefutable arguments that Israeli cultural and academic institutions should be held accountable both for their discriminatory policies and for their direct and indirect involvement in Israel's grave practices. As BRICUP's publication plainly states, if a normal situation to resolve grievances was in existence, then 'there would be no need for a boycott'. ${ }^{19}$

\section{Putting the Law in Context}

In contrast to the principled, consistent and thoroughly contextualized approach of the aforementioned authors explaining the moral and legal underpinnings of BDS, a rather different narrative can emerge when legal arguments are made in the absence of the social and political context in which violations take place.

In general, scholars in Europe, the US and elsewhere have been reluctant to criticize Israel. While there is by now a sizeable and growing body of critical literature, including the important work of John Dugard, ${ }^{20}$ as well as Akram et al, legal scholars have traditionally been the most reluctant of all scholars as they rarely delve into the social or political aspects of any conflict, let alone one as polarized as that between Israel and the Palestinians. ${ }^{21}$ While this is perhaps understandable in terms of how legal scholarship and education still maintains a largely positivist orientation - that makes erroneous claims of objectivity, impartiality and neutrality - it can have highly unfortunate consequences when key historical and political facts are ignored. ${ }^{22}$

One such study by a Dutch legal scholar, Dikker-Hupkes, examines legal questions around the law of occupation and more particularly on those questions applied to Gaza following Israel's withdrawal of Jewish-only settlements in 2005. These questions have come up on several occasions in the context of the decades-long occupation by Israel of various Palestinian territories. They have been revisited by legal scholars following the 2005 'withdrawal' of the Gaza Strip, questioning whether the territory continued to be occupied or even whether the occupation could be termed 'legal or illegal'. ${ }^{23}$

Dikker-Hupkes attempts to explain the history and breadth of the law of occupation and its specific application to the territory of Gaza. He provides a survey of what occupation is, i.e.

\footnotetext{
${ }^{18}$ (pp. 192-193).

${ }^{19}$ (p. 21).

${ }^{20}$ See Dugard and Reynolds (2013)

${ }^{21}$ See also Meloni and Tognoni (2012); Al-Haq (2012), a report endorsed by several prominent legal scholars; Kattan

(2009) and the 17 volumes (including this one) of the Palestine Yearbook of International Law.

${ }^{22}$ This section draws upon and develops J. Handmaker (2010).

${ }^{23}$ N Stephanopoulos (2006); Y Shany (2008); O. Ben-Naftali, A. M. Gross and K. Michaeli (2005).
} 
occurring in the context of an international armed conflict and evidenced by a factual situation of 'effective control' over a territory. He also provides a legal history of the modern law of occupation, charts its evolution ${ }^{24}$ and provides some comparative examples of other, recent occupations (including Morocco's ongoing occupation of Western Sahara and the occupation of Iraq by the US and its allies). ${ }^{25}$

However, after confirming that Gaza has continued to be occupied following Israel's so-called 'disengagement' of 2005, Dikker-Hupkes produces a confusing explanation of the context of Israel's post-2005 occupation of Gaza. He rightly clarifies that Israel's effective control extends beyond the territory's land, sea and water borders, but also covers essential services such as electricity, sewage, telecommunication and even the territory's population registry. He furthermore confirms that "sovereignty lies with the people" 26 , an important clarification in light of broader, national claims made by Palestinians. However, unlike Akram and her colleagues, Dikker-Hupkes doesn't deal with the crucial interconnectedness of this claim (being free of Israeli occupation in the Gaza strip) from other, core national claims, including the return of Palestinian refugees, the equality of Palestinian citizens of Israel and control over (East) Jerusalem. ${ }^{27}$

Furthermore, Dikker-Hupkes fails to explain the long-term implications of Israel's nearly 50year occupation of Palestinian territories, despite numerous UN Security Council resolutions calling for withdrawal from the territories occupied since 1967. Israel's belligerent occupation of the West Bank, including East Jerusalem, and the Gaza Strip has, in fact, involved numerous acts of military aggression and collective punishment against a largely defenseless civilian population, including Israel's so-called Operation Cast Lead in 2008-09. ${ }^{28}$

While Dikker-Hupkes confirms that the 'object and purpose of the Fourth Geneva Convention 'is the protection of the basic humanitarian needs of the civilian population' ${ }^{29}$ and that the Oslo Accords are largely irrelevant in relation to whether territory should be considered as occupied, ${ }^{30}$ his treatment of self-determination lacks a comprehensible political and factual context. In particular, he grossly simplifies key legal and historical events in the period leading up to, including and immediately following Israel's unilateral declaration of statehood in $1948 .{ }^{31}$ Notable historical omissions include the failure of the UN to implement General Assembly Resolution 181, as well as the fully anticipated consequences by Zionist militia groups of Israel's unilateral declaration of statehood and Israel's refusal to allow the return of nearly 1 million refugees displaced by the war, or forcibly expelled. ${ }^{32}$

A further, major flaw of the study is Dikker-Hupkes' responses to arguments posed by Professor Iain Scobbie. ${ }^{33}$ Rather than examine the social and political underpinnings of the Palestinian claim to self-determination, Dikker-Hupkes reduces this claim in relation to the Gaza territory as the "principal legal status of the self-determination unit". ${ }^{4}$ In other words, the author reduces Palestinian claims of self-determination to a claim over non-contiguous territories that the United States, EU and others have for some time regarded as the basis of the Palestinian claim in the context of a proposed, two-state solution. Faced with an unremitting construction in illegal settlements, the construction of walls, hundreds of roadblocks and other barriers throughout the West Bank and around the Gaza enclave, the so-

\footnotetext{
24 (Ibid: 11-15).

25 (Ibid: 45-48)

${ }^{26}$ (p.55).

${ }^{27}$ (Ibid: 306-309)

${ }^{28}$ According to a United Nations Commission led by Justice Richard Goldstone, the latter led to numerous war crimes. See United Nations (2009).

${ }^{29}$ (Ibid: 27,59 )

30 (Ibid: 62-63).

${ }^{31}$ See, for example, V. Kattan (2009).

${ }^{32}$ Kattan (Ibid) and I. Pappe (2007).

${ }^{33}$ I. Scobbie (2007).

${ }^{34}$ (Ibid: 76-82).
} 
called two-state solution has faced considerable challenges, both legally and with regard to the overwhelming 'facts on the ground', to the point that even the EU has even questioned the viability of a Palestinian state in the West Bank. ${ }^{35}$ Finally, Dikker-Hupkes fails to engage with the sectarian nature of the State of Israel, which denied Palestinians' right to selfdetermination already in 1948 and has systematically denationalized the majority of the country's Arab population, a matter that also questions the workability - let alone the desirability - of a two-state solution. ${ }^{36}$

By contrast, the book by Susan Akram and her colleagues Michael Dumper, Michael Lynk and Iain Scobbie, explores the deeper underpinnings of the Israel-Palestinian impasse. They comprehensively address the 'core issues' of refugees and Jerusalem in four solid chapters in part one of their book. Akram demystifies the nature of the Palestinian refugee issue with solid references to historical events and international law developments, ${ }^{37}$ followed by a contribution from Custer, who rigorously addresses the role of UN agencies, and in particular the United Nations Relief and Works Agency (UNRWA) ${ }^{38}$ Rempel and Prettitore follow by canvassing the legal and practical possibilities of obtaining restitution and compensation ${ }^{39}$ and finally Dumper disentangles various claims in relation to the status of Jerusalem. ${ }^{40}$ All contributions by these legal scholars, most of whom also have a distinguished career as legal practitioners, are both contextualized and firmly rooted in international legal obligations.

By failing to address the social and political context, one can easily end up with a naïve, albeit well-intentioned conclusion (as Dikker-Hupkes did) that ending the occupation of Gaza, in terms of relinquishing effective control, would "give the Palestinian people more than ever the opportunity to determine freely their political status without external interference". ${ }^{41}$ Such a conclusion misses entirely the question of what this future State would be comprised of - at the very least in the absence of a contiguous territory - which some have referred to as a 'bantustanized' collection of isolated enclaves in the remainder of the occupied territories. More fundamentally, such a conclusion fails to account for the legally entrenched, political and social aspirations of several million Palestinian refugees in the occupied territories, surrounding States and elsewhere in the world. Those who were dispossessed and displaced in various military conflicts from 1948 onwards and who have been denied a nationality also include Palestinian citizens of Israel.

Dikker-Hupkes' book raises important questions about the limits of doctrinal legal scholarship and reveals the need for a thorough coverage of international law and its potential contribution to resolving the long-standing impasse between Israel and the Palestinians. ${ }^{42}$ The book by Akram and her colleagues goes a very long way towards addressing these questions and filling this gap in a contextualized manner, not only addressing the "core issues" mentioned above, but also the much-neglected aspects of security for Palestinians, with contributions by Koury and Dajani. ${ }^{43}$ Quigley then proceeds to explore the prospects of legal and political frameworks to address the broader self-determination claims of Palestinians, ${ }^{44}$ followed by Scobbie's contribution on the exploitation of natural resources. ${ }^{45}$ Milhem and Salem close the third part of the book with their reflections on the futility of building a governmental system (the Palestinian Authority) based on the rule of law, in the absence of freedom from Israeli

\footnotetext{
35 D. Macintyre (2012).

36 J. Handmaker (2011)

(Ibid: 13-44)

38 (Ibid: 45-68).

39 (Ibid: 69-112).

40 (Ibid: 113-143).

${ }^{41}$ (Ibid: 80).

${ }^{42}$ J. Handmaker (2013)

43 (Ibid: 147-206)

44 (Ibid: 209-228).

45 (Ibid: 229-254).
} 
occupation. ${ }^{46}$ The fourth and final part of the book contains bold proposals, by Lustick and Bisharat, that contemplate alternative models of statehood from the "classical" two-state solution. ${ }^{47}$

If one aspect could be said to be missing in Akram and her colleagues' analysis, it is the treatment of the role of international law in addressing the plight of Palestinian prisoners. Some scholars have studied the highly disturbing treatment and psycho-social consequences of Israel's detention of Palestinians from a medical perspective.$^{48}$ However, with the exception of Kassim, ${ }^{49}$ there are comparatively limited scholarly studies addressing the international law aspects of Israel's arrest and detention of Palestinians, including the basic question of whether captured Palestinian resistance fighters ought to be treated as prisoners of war. ${ }^{50}$

This aside, Akram and her colleagues convincingly place international law in context and against core issues of the impasse between Israel and the Palestinians, raising the bar for (socio-)legal studies that critically address these issues. The authors also reveal the stark limitations of a purely legal-doctrinal approach, which is very often not only misleading, but even dangerous, betraying the fundamental principles upon which international law and its constitutive protective function, are based.

\section{Conclusion - Engaging with the Politics of (Non-)Violence}

The growth of serious scholarly literature addressing international law aspects and that develop the legal and moral underpinnings of BDS are much welcomed. This literature elaborates on BDS as an unambiguous, non-violent alternative to numerous, failed efforts to end the decades-long impasse between Israel and the Palestinians. However, as I argued in this review article, there is also a limit to the value of doctrinal legal arguments alone.

Barghouti makes a more direct observation, in relation to legal commentary on Israel's policies and actions in Gaza, including its blockade of the territory:

International law experts have debated whether Israel's crimes in Gaza, which largely conform to the UN definition of genocide, are committed with a clear intent - a necessary condition to consider these acts as constituting full-fledged genocide. ... While lawyers continue to argue, Palestinian "relative humans" are being subjected to what feels very much like slow genocide. Many Palestinian babies are still being born disfigured ... Palestinian soil and water are still being contaminated relentlessly ... Patients with chronic diseases as well as those suffering from a wide range of curable illnesses are dying a slow death, away from the mainstream media's radar. ${ }^{51}$

The uncomfortable mirror that Barghouti presents to socio-legal scholars is useful, which resonates with the critical legal critique posed by Koskenniemi ${ }^{52}$ and others, challenging legal scholars to speak to the social workings and the politics of law and not merely debate its doctrinal content. Yet Barghouti does not dismiss the value of law. Indeed, he firmly bases his arguments in terms of international law, fully contextualized to the historical, social and political context of the Palestinian legal experience. In so doing, he correspondingly reveals the incompatibility of Israeli law to universalized notions of justice and equality. This strengthens his arguments and reveals a crucial dimension in the debate on BDS - namely to question the very morality of Israeli laws, the very purpose of which are to maintain an apartheid system of dominance by Israeli Jews over Palestinian Arabs.

${ }^{46}$ (Ibid: 253-256)

47 (Ibid: 277-329)

${ }^{48}$ E. El Sarraj, R. Punamäki, S. Salmi and D. Summerfield (1996) and R. Punamäki, S. Qouta and E. El Sarraj (2010).

${ }^{49}$ Kassim.

${ }^{50}$ NGOs, on the other hand, have produced a great deal of important reports, including Amnesty International, Al-

Haq, Addameer and Defence for Children International-Palestine. See, for example DCI (2012) and Handmaker and Nieuwhof (2006)

${ }^{51}$ (Ibid: 46-47). Of interesting comparative / historical relevance, Dugard (1976) addressed this very issue in the context of South Africa's occupation of (then) Southwest Africa.

${ }^{52}$ Koskenniemi (2005). 
Criticisms of Israeli laws and legal arguments that seek to hold Israel accountable are regarded by Israel and many of its supporters as a form of violence and even as 'legal jihad'. ${ }^{3}$ Adopting this distorted logic, Israel considers itself justified in imposing draconian measures against individuals and organizations that merely call for BDS and which question the 'Jewish' nature of the state of Israel. These exceptionalist and morally-questionable arguments must be confronted by those constructing a legal argument in such a polarized environment and by those developing the legal and moral underpinnings of BDS. Judith Butler, a highly regarded scholar and professor of philosophy addresses this dilemma well in relation to those who, as she puts it, call for the "“destruction" of the current (Israeli) law governing rights of citizenship and political participation':

even nonviolent political solutions that suggest that the conditions of citizenship in Israel are in need of revision to include entitled Palestinians are accused of 'destroying' the State of Israel even when their means are decidedly nonviolent. These positions are regularly confused with those that do call for violent attacks on Israeli property and citizens, but in some important ways the former is a serious nonviolent alternative to the latter, and is regularly stigmatized as 'violent' nevertheless. It is perhaps ironic in this context to note that the boycott is understood by many of its supporters as precisely an alternative to violence, an effort to make use of established international institutions and precedents to demand action on behalf of those whose suffering under the Occupation has yet to be adequately addressed. ${ }^{54}$

In short, whether in developing international legal arguments that challenge the nature of Israeli law or in addressing the morality of Israel's legal system, policies and practices and the corresponding moral rightness of BDS as an instrument of non-violent resistance, one must also engage with the politics of violence and indeed resistance. ${ }^{55}$

The response to the Palestinian call for BDS from scholars abroad, from among Palestinians and from a small, but growing number of Israeli scholars has been overwhelming. One representative example was in September 2010, when a European Platform for the Academic and Cultural Boycott of Israel (EPACBI) was established in Paris, supported by groups of scholars from around the continent and in particular Britain, France, Sweden and Norway. PACBI, the US Academic Boycott Campaign ${ }^{56}$ and other initiatives have taken direction from scholars such as Barghouti and Butler, who both emphasize that there is nothing inconsistent whatsoever with addressing BDS as part of Palestinians' non-violent struggle for selfdetermination and critiquing the moral underpinnings of Israeli laws that have created an apartheid system against Palestinians, whether they are refugees, are living under Israeli occupation or have Israeli citizenship.

As mentioned at the start of this essay, similar legal and moral arguments proved extremely useful in advocating for the end of South Africa's apartheid regime in the 1990s and will, it is expected, continue to be of use in seeking to end Israel's apartheid regime. Scholars must, in light of these compelling arguments, take academic freedom seriously by critically engaging individual Israeli academics and isolating Israeli institutions that are complicit in violations of the rights of Palestinians.

\section{Additional References}

S. Akram and M. Lynk (2006), 'The wall and the law: a tale of two judgements', Netherlands Quarterly of Human Rights, Vol. 24(1), 61.

Al-Haq (2012) Legal Memorandum on State Responsibility in Relation to Israel's Illegal Settlement Enterprise available on the website of Al-Haq at: http://www.alhaq.org/ (last checked on 6 December 2012).

\footnotetext{
${ }^{53}$ B. Goldstein and E. Aaron (2009).

54 J. Butler (2006) at 15 .

${ }^{55}$ (Barghouti 2011: 49-62).

${ }^{56}$ For more information, see: www.usacbi.org, last checked on 26 January 2012.
} 
N.B. Final Author Version for RePub, appearing in The Palestine Yearbook of International Law (Vol. 17 2013-14), Publication date: July 2015

O. Ben-Naftali, A. M. Gross and K. Michaeli (2005), 'Illegal Occupation: Framing the Occupied Palestinian Territory' 23 Berkeley Journal of International Law, 551.

J. Butler (2006) 'Israel/Palestine and the paradoxes of academic freedom' Radical Philosophy 135 (January/February), 8-17.

J. Dugard (1976), 'SWAPO: the jus ad bellum and the jus in bello' 93 The South African Law Journal, 144.

J. Dugard and J. Reynolds (2013), 'Apartheid, International law and the Occupied Palestinian Territory' 24 European Journal of International Law, 867.

E. El Sarraj, R. Punamäki, S. Salmi and D. Summerfield (1996), 'Experiences of torture and ill-treatment and posttraumatic stress disorder symptoms among Palestinian political prisoners' Journal of Traumatic Stress 9(3), 595.

B. Goldstein and E. Aaron (2009) 'Legal Jihad: How Islamist Lawfare Tactics are Targeting Free Speech’15 ILSA Journal of International \& Comparative Law 395.

J. Handmaker and A. Nieuwhof (2006), 'Leven in de hel: administratieve detentie in de bezette gebieden', (Translation: Life in hell: administrative detention in the occupied territories') Wordt Vervolgd, 39, 6-9.

J. Handmaker (2007), 'Academic freedom is the issue' Holy Land Studies 2007 6(2), 218.

J. Handmaker (2010), 'Looking Beyond the Law', Review essay of S.D. Dikker Hupkes, What Constitutes Occupation? Israel as the Occupying Power in the Gaza Strip after Disengagement Netherlands Quarterly of Human Rights, Vol. 28(2), 279.

J. Handmaker (2011), 'Beyond Exclusion: Assessing Palestinian Refugees? Struggle for Protection and Recognition and their Potential Contribution to a Peace Settlement' (197-222) in K. van der Borght, K. Byttebier \& C. Mackenzie (Eds.), Imagining a Shared Future: Perspectives on Law, Conflict and Economic Development in the Middle East.

J. Handmaker (2013), 'In Search of a Human Face in the Middle East: Addressing Israeli Impunity for War Crimes' (155-168) in M. Matthee et al. (eds.) Armed Conflict and International Law : in Search of the Human Face: Liber Amicorum in Memory of Avril McDonald.

A. Kassim (1980), 'Palestine Liberation Organization's Claim to Status: A Juridical Analysis under International Law', 9 Denver Journal of International Law and Policy 1.

V. Kattan (2009) From Conquest to Co-existence: International Law and the Origins of the Arab-Israeli Conflict, 1891-1949.

M. Koskenniemi (2005) From Apology to Utopia: The Structure of International legal Argument.

D. Macintyre (2012) 'EU on verge of abandoning hope for a viable Palestinian state', The Independent, 12 January 2012, last accessed on 26 January 2012 at: http://www.independent.co.uk/news/world/middle-east/eu-on-verge-of-abandoninghope-for-a-viable-palestinian-state-6288336.html\#

N. Masalha (2003) The Politics Of Denial: Israel and the Palestinian Refugee Problem.

C. Meloni and G. Tognoni (2012) Is There a Court for Gaza? A Test Bench for International Justice

I. Pappe (2007) The Ethnic Cleansing of Palestine. 
N.B. Final Author Version for RePub, appearing in The Palestine Yearbook of International Law (Vol. 17 2013-14), Publication date: July 2015

R. Punamäki, S. Qouta and E. El Sarraj (2010), 'Nature of torture, PTSD, and somatic symptoms among political ex-prisoners' Journal of Traumatic Stress, 23, 532.

I. Scobbie (2007), 'An Intimate Disengagement: Israel's Withdrawal from Gaza, the Law of Occupation and of Self-Determination' (3-31) in E. Cotran and M. Lau (eds.), Yearbook of Islamic and Middle Eastern Law, Volume 11.

Y Shany (2008) 'Binary Law Meets Complex Reality: The Occupation of Gaza Debate', Israel Law Review, 68.

N Stephanopoulos (2006), 'Israel's Legal Obligations to Gaza After the Pullout' 31 Yale Journal of International Law, 524.

United Nations (2009), Human Rights in Palestine and other Occupied Arab Territories: Report of the United Nations Fact Finding Mission on the Gaza Conflict, UN Doc. A/HRC/12/48, 15 September 2009. 